\title{
Capacity to control oxidative stress-induced caspase-like activity determines the level of tolerance to salt stress in two contrasting maize genotypes
}

Marshall Keyster, Ashwil Klein, Morné Du Plessis, Alex Jacobs, Abidemi Kappo, Gábor Kocsy, Gábor Galiba and Ndiko Ludidi

\begin{abstract}
The response of two maize (Zea mays L.) genotypes, named GR (salt-tolerant) and SK (saltsensitive), to salt stress (150 $\mathrm{mM} \mathrm{NaCl}$ ) was investigated under controlled environmental growth conditions. Genotype SK experienced more oxidative damage than the GR genotype when subjected to salt stress, which corresponded to higher $\mathrm{O}_{2}$ - production rate and $\mathrm{H}_{2} \mathrm{O}_{2}$ content in the SK genotype than the GR genotype. Induction of caspase-like activity in response to salt stress was stronger in the SK genotype than in the GR genotype. On the other hand, induction of antioxidant enzyme activity to scavenge $\mathrm{O}_{2}-$ and $\mathrm{H}_{2} \mathrm{O}_{2}$ in response to salt stress was weaker in the SK genotype than in the GR genotype. Consequently, the higher level of oxidative damage in the SK genotype in response to salt stress was manifested as more extensive cell death and biomass reduction in the SK genotype than it was in the GR genotype. Our results suggest that a direct relationship exists between salt stress-induced oxidative damage and cell death-inducing caspase-like activity, with tolerance to the salt stress being controlled by the efficiency of the plantantioxidant enzymes in limiting salt stress-induced oxidative damage and thus limiting cell death-inducing caspase-like activity.
\end{abstract}

\section{Introduction}

Salinity stress adversely affects plant growth and can lead to plant cell death and severe reduction of crop yield because of its negative effects on diverse plant biochemical and physiological processes (Parida and Das 2005). The effects of salinity on these processes are partly due to generation of reactive oxygen species (ROS) such as the superoxide anion $\left(\mathrm{O}_{2}^{-}\right)$and hydrogen peroxide $\left(\mathrm{H}_{2} \mathrm{O}_{2}\right)$, which trigger augmented antioxidant enzyme activities as a defence mechanism against ROS-induced oxidative damage (Gé mes et al. 2011; Mallik et al. 2011; Noreen et al. 2010; Sairam et al. 2005). One of the consequences of ROS overproduction in response to salt stress is lipid peroxidation, manifested as oxidative damage to lipids that constitute cell and organelle membranes that can be estimated on the basis of malondialdehyde (MDA) content (Ellouzi et al. 2011). Plants with enhanced ability to scavenge ROS (which we refer to as enhanced antioxidant capacity) and improved ability to prevent cell death under salinity stress may thus have 
enhanced tolerance against salt stress (Miller et al. 2010; Tseng et al. 2007; Wu et al. 2008).

Antioxidant enzymes that control the biosynthesis and utilization of antioxidant metabolites such as glutathione and ascorbate to detoxify ROS (Foyer and Noctor 2005; Miller et al. 2010; Mittler 2002) intricately regulate antioxidant capacity. ROS are thought to be key inducers of programed cell death in plants (De Pinto et al. 2012) and antioxidants have an important role in this process (Li et al. 2007). Furthermore, programed cell death that may be triggered by salt stress-induced oxidative stress may in part be controlled by caspase-like cysteine endopeptidase activity (Miller et al. 2010; Solomon et al. 1999; Wang et al. 2010) and by metacaspases (He et al. 2008). Caspases belong to proteases of the cysteine endopeptidase (EC 3.4.22) family and are vital for the execution of programed cell death in plant tissue (Naito et al. 2000; Vincent and Brewin 2000; Groten et al. 2006). Cysteine endopeptidase activity is instrumental in the execution of programed cell death in plants in response to salt stress, as seen for caspase-like activity in suspension-cultured cells of Thellungiella halophila plants (Wang et al. 2010) and in the mesophyll of tobacco (Andronis and Roubelakis-Angelakis 2010) exposed to $\mathrm{NaCl}$. Interestingly, the involvement of other types of plant caspases, such as metacaspase8, has been demonstrated in ultraviolet light and $\mathrm{H}_{2} \mathrm{O}_{2}$ - induced oxidative stress in Arabidopsis (He et al. 2008). It thus appears that induction of caspase activity by abiotic stresses, including salt stress, may be transduced via ROS production in response to abiotic stresses. Cysteine endopeptidase-specific inhibitory proteins known as cystatins (Solomon et al. 1999) can control the ROS-activated caspase-like activity and these cystatins thus present a mechanism by which ROS-mediated programed cell death can be regulated under abiotic stress. The involvement of cystatins in the regulation of abiotic stress tolerance has been demonstrated for Arabidopsis thaliana (Zhang et al. 2008).

Recent evidence suggests that plant genotypes with contrasting tolerance to some abiotic stresses have contrasting antioxidant enzyme activities when exposed to these stresses. This has been suggested for cowpea (Vigna inguiculata L.) and turnip (Brassica rapa L.) cultivars during salinity stress (Maia et al. 2010; Noreen et al. 2010), salt-tolerant Hordeum marinum Huds versus salt-sensitive Hordeum vulgare L. (Seckin et al. 2010), maize (Zea mays L.) seedlings exposed to cadmium stress (Ekmekç i et al. 2008), wheat (Triticum aestivum L.) exposed to salt stress (Mandhania et al. 2006), rice (Oryza sativa L.) during salt stress (Vaidyanathan et al. 2003) and cotton (Gossypium hirsutum L.) seedlings exposed to salt stress (Gossett et al. 1994). Despite this extensive number of reports on the role of antioxidant enzymatic activities in regulating plant responses to abiotic stresses, reports on caspase-like activity as a key regulator of salt stress responses are limited. Furthermore, short-term effects of salt stress on maize biochemical and physiological responses are well documented but the long-term effects of salt stress (which are more reflective of field conditions) on such processes in maize are scarce. It was on this basis that we investigated lipid peroxidation, ROS accumulation, antioxidant enzyme activities, caspase-like enzymatic activities, cell death and growth responses in two maize genotypes with contrasting levels of tolerance (one sensitive and the other tolerant) to salt 
stress to establish if any relationship exists between the level of salt stress tolerance and the physiological/biochemical processes studied in this report.

\section{Materials and methods}

\section{Plant material, treatments and experimental design}

Maize (Zea mays L.) seeds of commercial proprietary genotypes (kindly donated by Capstone Seeds Pty Ltd, Howick, South Africa) code-named GR and SK were surface sterilized in $0.35 \%$ sodium hypochlorite for $10 \mathrm{~min}$, followed by 5 washes with sterile distilled water. The maize seeds were imbibed in sterile distilled water for $1 \mathrm{~h}$ and sown in 2 l of filtered silica sand $\left(98 \% \mathrm{SiO}_{2}\right.$, Rolfes ${ }^{\circledR}$ Silica, Brits, South Africa) that had been presoaked in distilled water, in $20 \mathrm{~cm}$ diameter plastic pots. The sand was kept moist by watering only with distilled water during germination.

Germinated seedlings (thinned out so that there was one plant per pot) were grown on a $25 / 19{ }^{\circ} \mathrm{C}$ day/night temperature cycle under a $16 / 8 \mathrm{~h}$ light/dark cycle, at a photosynthetic photon flux density of $300 \mathrm{lmol}$ photons $\mathrm{m}^{-2} \mathrm{~s}^{-1}$ during the day phase, in a completely randomized design so that plants are randomly placed (instead of placing the plants in groups on the basis of the kind of treatment applied) in the growth chamber to eliminate the effect of variations in environmental conditions at different positions in the growth chamber on any of the parameters measured across the treatments. Plants were supplied with nutrient solution composed of $1 \mathrm{mM} \mathrm{K}_{2} \mathrm{SO}_{4}, 2 \mathrm{mM} \mathrm{MgSO}_{4}, 10 \mathrm{mM} \mathrm{CaCl}_{2}, 5 \mathrm{mM} \mathrm{KNO} \mathrm{KN}_{3}, 10 \mathrm{mM}$ $\mathrm{NH}_{4} \mathrm{NO}_{3}, \quad 1 \mathrm{mM} \quad \mathrm{K}_{2} \mathrm{HPO}_{4}$ buffer at $\mathrm{pH} \quad 6.4,5 \mathrm{lM}_{3} \mathrm{H}_{3} \mathrm{BO}_{3}, 5 \mathrm{lM} \quad \mathrm{MnSO}_{4}, 1 \mathrm{lM}$ $\mathrm{ZnSO}_{4}, 1 \mathrm{lM} \mathrm{CuSO} 4,2 \mathrm{lM} \mathrm{Na} \mathrm{MoO}_{4}, 1 \mathrm{lM} \mathrm{CoSO}_{4}, 100 \mathrm{lM} \mathrm{Fe-NaEDTA}$ and $5 \mathrm{mM} 2-$ ( $N$-Morpholino)ethanesulfonic acid (MES) at pH 6.4 when they reached the V1 stage (when the collar of the first leaf was visible). It was at this stage that salt stress was imposed. Plants of the same phenological stage and similar height were selected for all experiments.

For treatment with $\mathrm{NaCl}$ to impose salt stress, $200 \mathrm{ml}$ of nutrient solution containing $\mathrm{NaCl}$ at a final concentration of $150 \mathrm{mM}$ was applied (at intervals of 3 days between each treatment) to each plant by adding the solution directly to the sand at the base of the stem of the plant for a total period of 21 days. Control plants were treated in a similar manner except that nutrient solution without $\mathrm{NaCl}$ was used for the control plants.

Several molecular/biochemical and dry weights were evaluated immediately after 21 days of salt treatment. Freshly harvested plants were used for measurement of $\mathrm{O}_{2}{ }^{-}$ accumulation, cell death and dry weights but snap-frozen (in liquid nitrogen) tissue was used for all other assays (in which case the tissue was stored at $-80{ }^{\circ} \mathrm{C}$ and used within 2 days).

\section{Measurement of plant dry weight}

Plants were removed from the sand, being careful to avoid any loss of shoots or roots during the up-rooting of the plants. Ten plants from each treatment (nutrient solution only or 
nutrient solution supplemented with $\mathrm{NaCl}$ ) were divided into shoots (area immediately above the hypocotyl) and roots (area immediately below the hypocotyl). The shoots and roots were dried separately in an oven at $80{ }^{\circ} \mathrm{C}$ for $72 \mathrm{~h}$ to determine dry weights (moisture uptake was prevented by keeping plant tissue in desiccators containing silica gel).

\section{Measurement of cell viability}

Leaves and roots from each genotype were assayed for cell viability as described by Sanevas et al. (2007) for plant tissue. For this assay, leaves and roots were harvested and stained with $0.25 \%(\mathrm{w} / \mathrm{v})$ Evans Blue for $15 \mathrm{~min}$ at room temperature. The leaves or roots were then washed for $30 \mathrm{~min}$ in distilled water, followed by extraction of the Evans Blue stain from leaf or root tissue using $1 \%$ (w/v) SDS after incubation for $1 \mathrm{~h}$ at $55{ }^{\circ} \mathrm{C}$. Absorbance of the extract was measured at $600 \mathrm{~nm}$ to determine the level of Evans Blue taken up by the leaf or root tissue.

\section{Assays for ROS accumulation}

We investigated if $\mathrm{O}_{2}{ }^{-}$and $\mathrm{H}_{2} \mathrm{O}_{2}$ content differed between the two maize genotypes upon treatment with $\mathrm{NaCl}$. For $\mathrm{O}_{2}^{-}$determination, a method modified from that described by Able et al. (1998) was used. $\mathrm{O}_{2}{ }^{-}$was determined by obtaining shoot and root sections $\left(1 \mathrm{~cm}^{2}\right.$ for leaf sections or $2 \mathrm{~cm}$ from the root tip for root sections, to a total fresh weight of $100 \mathrm{mg}$ ) from each treatment or corresponding control. The sections were washed twice with distilled water and then incubated at room temperature for $20 \mathrm{~min}$ in $0.12 \mathrm{mM}$ XTT in $50 \mathrm{mM}$ phosphate buffer, $\mathrm{pH}$ 8.2. The tissue was removed, and the assay solution was centrifuged $(13,000 \mathrm{~g}$ for $5 \mathrm{~min})$. The absorbance of the supernatant was measured at $450 \mathrm{~nm}$ and expressed as nanomoles of superoxide generated per minute per gram of tissue, using the molar extinction coefficient for the XTT formazan product of $23,600 \mathrm{M}^{-1} \mathrm{~cm}^{-1}$.

$\mathrm{H}_{2} \mathrm{O}_{2}$ content was determined in leaves and roots of each genotype at the end of the 21 days of salt treatment. The leaves or roots were assayed for $\mathrm{H}_{2} \mathrm{O}_{2}$ content based on a method adapted from Velikova et al. (2000). Plant tissue (200 $\mathrm{mg}$ ) was ground into a fine powder in liquid nitrogen. The tissue was homogenized in $800 \mathrm{ll}$ of cold $5 \%(\mathrm{w} / \mathrm{v})$ trichloroacetic acid (TCA). The homogenate was centrifuged at 12,ooog for $30 \mathrm{~min}$ at $4{ }^{\circ} \mathrm{C}$ to obtain the $\mathrm{H}_{2} \mathrm{O}_{2}$ extract. The reaction mixture contained $50 \mathrm{ll}$ of the extract, $5 \mathrm{mM}$ $\mathrm{K}_{2} \mathrm{HPO}_{4}, \mathrm{pH} 5.0$ and $0.5 \mathrm{M}$ KI. Samples were incubated at $25{ }^{\circ} \mathrm{C}$ for $20 \mathrm{~min}$ and absorbance readings of the samples were taken at $390 \mathrm{~nm} . \mathrm{H}_{2} \mathrm{O}_{2}$ content was calculated based on a standard curve constructed from the absorbance $\left(A_{390} \mathrm{~nm}\right)$ of $\mathrm{H}_{2} \mathrm{O}_{2}$ standards.

\section{Measurement of lipid peroxidation}

Lipid peroxidation (reflected by MDA content) was measured in leaf and root tissue by grinding leaf or root tissue $(200 \mathrm{mg}$ ) into a fine powder in liquid nitrogen. The tissue was 
homogenized in 80011 of cold $5 \%(\mathrm{w} / \mathrm{v})$ TCA. The homogenate was centrifuged at $12,000 \mathrm{~g}$ for $30 \mathrm{~min}$ and further processed based on the method of Buege et al. (1978).

\section{Determination of caspase-like activity}

We investigated if caspase-like activity differed between the two maize genotypes amongst the salt treatments. For assaying caspase-like activity, leaves and roots (only the second youngest leaf of each plant to ensure uniformity and sufficient plant material for the rest of the assays) of each genotype were used at the end of the 21 days of salt treatment. For this assay, $200 \mathrm{mg}$ of leaf or root tissue was ground in liquid nitrogen into a fine powder and homogenised in $2 \mathrm{ml}$ of assay buffer containing $100 \mathrm{mM}$ Tris- $\mathrm{HCl}(\mathrm{pH} 7.2), 5 \mathrm{mM}$ $\mathrm{MgCI}_{2}, 2 \mathrm{mM}$ EDTA, $10 \%$ (v/v) glycerol, $10 \mathrm{mM}$ b-mercaptoethanol, and $1 \mathrm{mM}$ phenylmethylsulfonyl fluoride (PMSF). Addition of PMSF was done in order to inhibit other classes of proteases, such as serine proteases, since cysteine protease inhibition by PMSF is reversed in the presence of b-mercaptoethanol but inhibition of other classes of proteases by PMSF is not reversed by b-mercaptoethanol.

The tissue extract was centrifuged at $13,000 \mathrm{~g}$ for $30 \mathrm{~min}$ at $4{ }^{\circ} \mathrm{C}$, followed by removal of the supernatant, which was then used as tissue extract for the assay. At this stage, $20 \mathrm{ll}$ of the tissue extract was incubated in $70 \mathrm{ll}$ of assay buffer at $37{ }^{\circ} \mathrm{C}$ for $5 \mathrm{~min}$, followed by addition of $10 \mathrm{ll}$ of $5 \mathrm{mM} \quad N$-Acetyl-Asp-Glu-Val-Asp- $p$-Nitroanilide (Ac-DEVD-pNA) as substrate (dissolved in dimethyl sulfoxide) for caspaselike activity to a final concentration of $0.5 \mathrm{mM}$. A blank reaction was set up in which Ac-DEVD-pNA was substituted with $10 \mathrm{ll}$ of DMSO. These reaction mixtures were incubated at $37{ }^{\circ} \mathrm{C}$ for $60 \mathrm{~min}$, within which caspase-like activity was followed by measuring absorbance at $405 \mathrm{~nm}$ every 20 min during the 6o-min incubation period. Caspase-like activity was calculated using the extinction coefficient of $9.6 \mathrm{mM}^{-1} \mathrm{~cm}^{-1}$ for the $p$-nitroaniline.

\section{Assays for antioxidant enzyme activity}

Enzyme extracts were obtained from the leaves (only the second youngest leaf of each plant to ensure uniformity and sufficient plant material for the rest of the assays) and roots by grinding plant tissue (leaves or roots) into a fine powder in liquid nitrogen and homogenizing $200 \mathrm{mg}$ of the tissue with $1 \mathrm{ml}$ of homogenizing buffer consisting of 40 $\mathrm{mM} \mathrm{K} \mathrm{HPO}_{4}, \mathrm{pH} 7.4,1 \mathrm{mM}$ EDTA and $5 \%$ (w/v) polyvinyl-pyrrolidone (molecular weight $=40,000$ ). The resulting homogenates were centrifuged at $12,000 \mathrm{~g}$ for $30 \mathrm{~min}$ and the supernatants were used for enzyme assays.

For total superoxide dismutase (SOD, EC 1.15.1.1) activity, leaves or roots of each genotype were used. The leaves or roots were assayed for SOD activity using a procedure based on the method described by Beyer and Fridovich (1987). The reaction mixture contained 50 $\mathrm{mM} \mathrm{K}_{2} \mathrm{HPO}_{4}, \mathrm{pH}$ 7.8, $0.1 \mathrm{mM}$ EDTA, $0.025 \%$ (w/v) Triton X-100, $0.1 \mathrm{mM}$ xanthine, $6.25 \mathrm{nM}$ xanthine oxidase, $0.1 \mathrm{mM}$ 2-(4-iodophenyl)-3-(4-nitrophenyl)-5-(2,4-disulfophenyl)-2H-tetrazolium (WST-1) and $10 \mathrm{ll}$ of extract. The reaction mixture was incubated for $20 \mathrm{~min}$ at $37^{\circ} \mathrm{C}$ and absorbance readings were taken at $450 \mathrm{~nm}$. SOD 
activity was calculated based on the amount of enzyme that was required to cause $50 \%$ decrease in the reduction of WST-1.

For total ascorbate peroxidase (APX, EC 1.11.1.11) activity, leaves and roots of each genotype were used for assaying ascorbate peroxidase activity using a procedure adapted from Asada (1984). For this assay, extracts were supplemented with ascorbate at a final concentration of $2 \mathrm{mM}$. The reaction mixture contained $10 \mathrm{ll}$ of extract, $50 \mathrm{mM}$ $\mathrm{K}_{2} \mathrm{HPO}_{4}, \mathrm{pH} 7.0,0.1 \mathrm{mM}$ EDTA, $50 \mathrm{mM}$ ascorbate, $1.2 \mathrm{mM} \mathrm{H}_{2} \mathrm{O}_{2}$ in a $200 \mathrm{ll}$ reaction. APX activity was calculated based on the change in absorbance at $290 \mathrm{~nm}$ as ascorbate was oxidised during the reaction, using the extinction co-efficient of $2.8 \mathrm{mM}^{-1} \mathrm{~cm}^{-1}$.

\section{Determination of protein concentrations}

Protein concentrations for all assays were measured in extracts derived from homogenizing buffer as described by the manufacturer for the RC DC Protein Assay Kit 11 (Bio-Rad Laboratories, Inc., Hercules, CA).

\section{Statistical analysis}

All experiments described were performed three times independently, with measurements taken from three (for all other measurements) or ten (for dry weight measurements) different plants for each treatment in each of the three independent experiments. Oneway analysis of variance (ANOVA) test was used to analyse all data and mean (of three independent experiments) was compared by the Tukey-Kramer test at $5 \%$ level of significance, using GraphPad Prism 5.03 software.

\section{Results}

Given that salt stress negatively affects plant growth (Parida and Das 2005), we compared dry weights between the SK and the GR genotypes at the end of the treatment period. Dry weights of both genotypes were negatively affected by salt treatment but reduction in shoot and root dry weights was more severe in the SK genotype than the GR genotype in response to salt treatment for both shoots (Fig. 1a) and roots (Fig. 1b). It is noteworthy that leaf rolling and leaf chlorosis occurred in both genotypes in response to the salt stress in this study and the leaves of both genotypes were smaller in the salt-treated plants than the leaves of the corresponding controls (results not shown). However, the extent of leaf rolling, chlorosis and reduction in leaf size was more prominent in the SK genotype than the GR genotype (results not shown). Plants treated with salt suffered a loss in cell viability, as indicated by an increase in the uptake of Evans Blue (which is indicative of cell death) in leaves and roots of both genotypes (Fig. 1c, d) upon salt treatment. The loss of cell viability was higher in salt-treated SK than in salt-treated GR compared to the corresponding controls (Fig. 1c, d). 

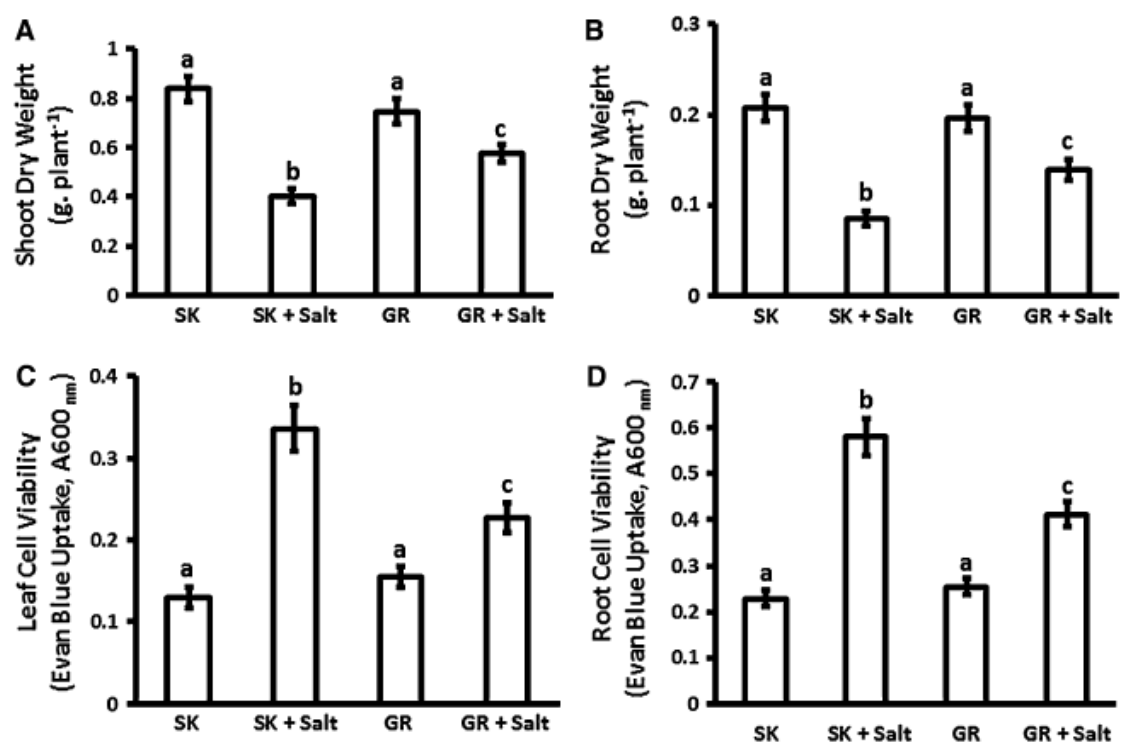

Fig. 1 Synergy between biomass and cell death in response to salt
stress. The effect of salt stress, resulting from treatment with $150 \mathrm{mM}$
$\mathrm{NaCl}$, on shoot (a) and root (b) dry weights and on cell death in leaves
(c) and roots (d) in two maize genotypes (GR and SK) was

determined. Data represent measurements at the end of the entire salt treatment (i.e. covering a total treatment period of 21 days) and are mean \pm standard error of three (for cell death) or ten (for dry weights) different plants, representing three independent experiments

Abiotic stresses such as salt stress cause generation of ROS (Miller et al. 2010) and hence it is possible that maize genotypes with contrasting responses to salinity stress may have different ROS accumulation profiles. We thus investigated if the $\mathrm{H}_{2} \mathrm{O}_{2}$ content in the two genotypes differed in response to salt treatment. $\mathrm{H}_{2} \mathrm{O}_{2}$ content increased moderately in salt-treated GR compared to the corresponding controls, whereas the $\mathrm{H}_{2} \mathrm{O}_{2}$ content increased much more drastically for SK in response to salt treatment, for both the leaves (Fig. 2a) and the roots (Fig. 2b). Excessive levels of ROS, which cause oxidation of cellular macromolecules (lipids, nucleic acids and proteins), can trigger activation of cysteine endopeptidase enzymatic activity such as caspaselike activity (De Azevedo Neto et al. 2006; Miller et al. 2010; Mittler 2010; Solomon et al. 1999; Wang et al. 2010). It was on this basis that we investigated if the level of caspase-like enzymatic activity differed between these two maize genotypes. Caspase-like enzymatic activity increased in leaves and roots for both the GR and SK genotypes in response to salt treatment compared to untreated controls (Fig. 2c, d). However, the leaf caspase-like enzymatic activity in salt-treated GR was only \pm onefold more than that of the untreated GR control, in contrast to ttwofold more caspase-like enzymatic activity for salt-treated SK in comparison to the corresponding SK control (Fig. 2c). Similarly, the root caspase-like enzymatic activity in salt-treated GR was only \pm onefold more than that of the untreated GR control, whereas the caspase-like enzymatic activity in roots of salt-treated SK was \pm threefold in comparison to the corresponding SK control Superoxide dismutase enzymatic activity is one of the major routes for the detoxification of $\mathrm{O}_{2}^{-}$(De Azevedo Neto et al. 2006; Foyer and Noctor 2005) and is augmented in response to various abiotic stresses in plants, including salt stress (Mittler 2002; Mittler et al. 2004, 2010). We thus set out to establish if superoxide dismutase enzymatic activity in these two genotypes differs. Leaf SOD activity increased in both GR and SK in response to salt treatment but the increase was more pronounced in GR than in SK in response to salt treatment compared to the corresponding untreated controls 
(Fig. 3a). However, root SOD activity in SK was inhibited by the salt treatment whereas it was induced in GR by the salt treatment (Fig. 3b).

Given that SOD acts to convert $\mathrm{O}_{2}{ }^{-}$into $\mathrm{H}_{2} \mathrm{O}_{2}$ and $\mathrm{O}_{2}$ (Beyer and Fridovich 1987; Foyer and Noctor 2005; Mittler 2002), it would be expected that elevated SOD activity would lead to accumulation of $\mathrm{H}_{2} \mathrm{O}_{2}$. Accumulation of $\mathrm{H}_{2} \mathrm{O}_{2}$ can trigger augmented ascorbate peroxidase (APX) activity in an attempt by the cells to detoxify the $\mathrm{H}_{2} \mathrm{O}_{2}$ thus measured APX enzymatic activity to establish if the trend of this enzymatic activity observed for SOD would be maintained for APX under the same conditions. The degree of increase in APX enzymatic activity in leaves and roots was more pronounced in GR than in SK in response to salt treatment (Fig. 3c, d).
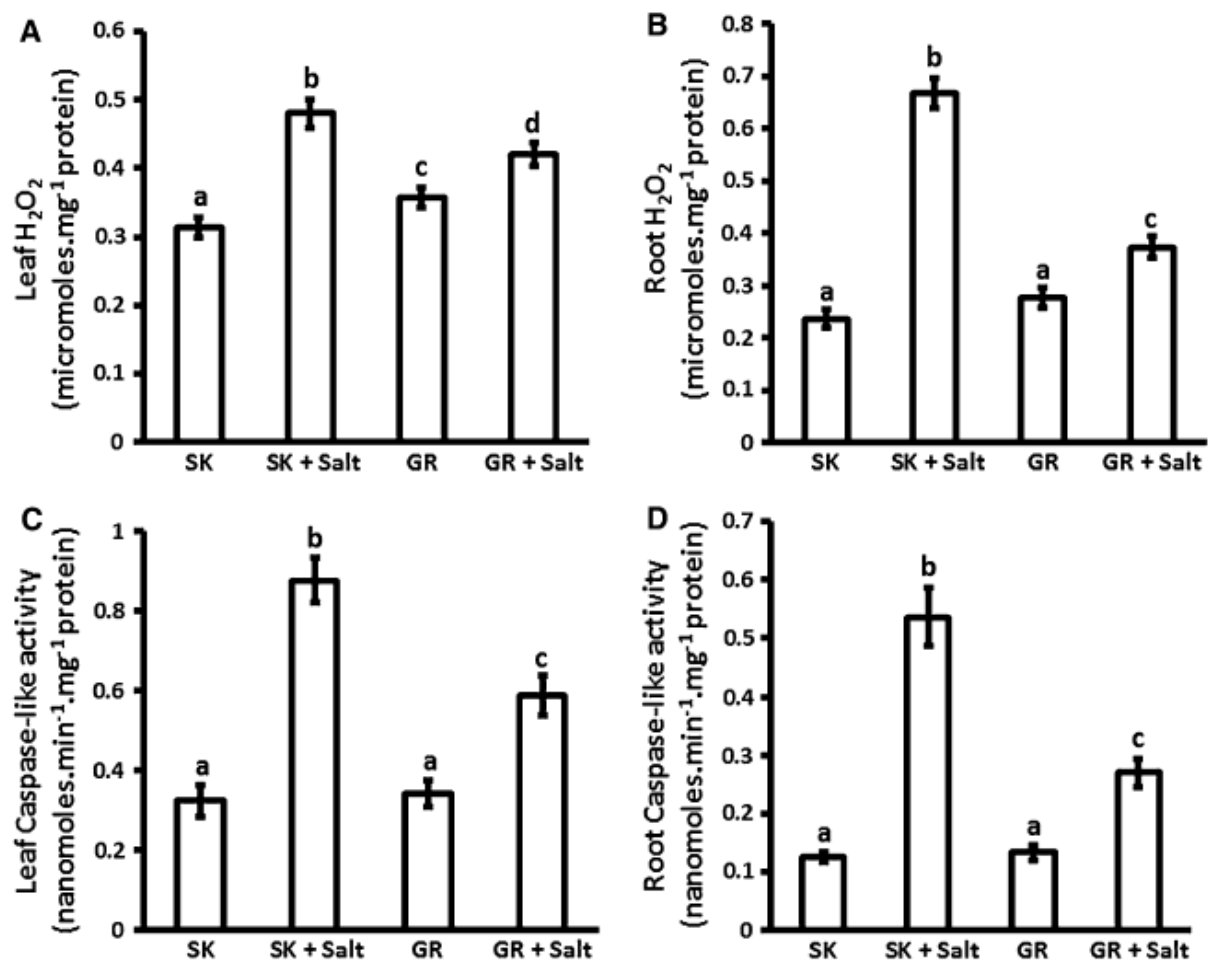

Fig. 2 Influence of salt stress on $\mathrm{H}_{2} \mathrm{O}_{2}$ content and caspase-like activity. Changes in $\mathrm{H}_{2} \mathrm{O}_{2}$ content in leaves (a) and roots (b) of GR and $\mathrm{SK}$ in response to treatment with $150 \mathrm{mM} \mathrm{NaCl}$ and caspase-like activity in leaves (c) and roots (d) after exposure to $150 \mathrm{mM} \mathrm{NaCl}$

were measured 21 days after treatment with the salt stress. Data represent mean \pm standard error of three different plants for each treatment, representative of three independent experiments

Excessive ROS levels result in oxidative stress, for which lipid peroxidation is one of the biochemical markers, and ultimately results in cell death if the plant cannot present efficient defences against the stress (Miller et al. 2010; Wang et al. 2010). We thus investigated if lipid peroxidation (estimated from MDA content) in the two genotypes differed in response to salt treatment. Leaf MDA content increased moderately in salttreated GR, whereas the leaf MDA content increased much more drastically for SK in response to salt stress, compared to the corresponding controls in both the leaves (Fig. 4a) and the roots (Fig. 4b). A similar trend was observed for $\mathrm{O}_{2}{ }^{-}$accumulation, for 
which a more prominent increase in $\mathrm{O}_{2}$ increase seen in GR in leaves (Fig. 4c) and roots (Fig. 4d).

\section{Discussion}

On the basis of the effects of salt stress on biomass (deduced from dry weight measurements), the observation that salt treatment induces more extensive loss in growth of the SK genotype than it does for the GR genotype, together with the observation that more extensive unfavourable changes in leaf morphology/appearance occurred in the SK genotype than in the GR genotype, implies that the SK genotype can be regarded as more sensitive to salt stress than the GR genotype. This is supported further by the fact that the extent of cell death (loss of cell viability as indicated by the extent of Evans Blue uptake) was more severe in the SK genotype than the GR genotype in response to salt stress.
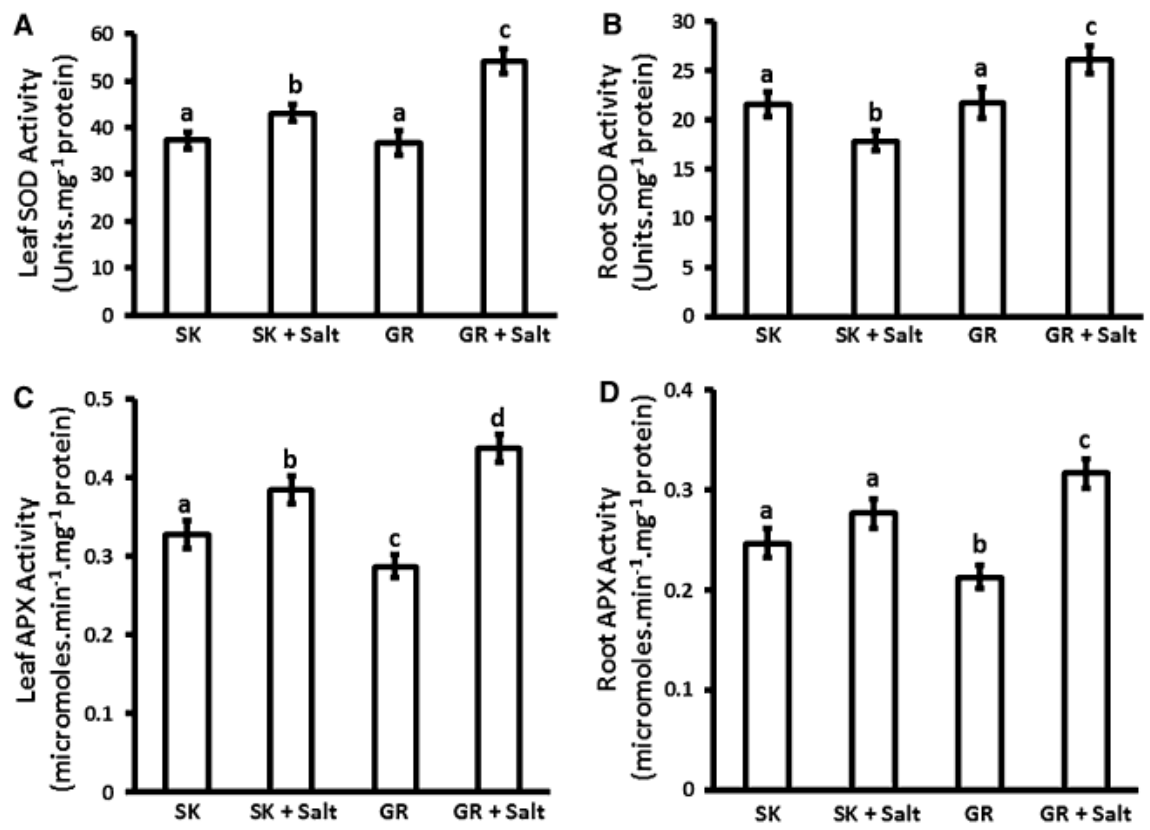
Fig. 3 Differential responses of antioxidant enzymes to salt stress.
Superoxide dismutase (SOD) activity in leaves (a) and roots (b) of the
two genotypes after exposure to salt stress, together with ascorbate peroxidase (APX) enzymatic activity in leaves (c) and roots (d) of the

$\mathrm{SK}$ and the GR genotype in response to treatment with $150 \mathrm{mM} \mathrm{NaCl}$ were measured 21 days after exposure to salt stress. Data are mean \pm standard error of three different plants, representing three independent experiments

The observed increase in cell death in response to salt stress in the two genotypes can either be necrotic death or programed cell death and this remains to be investigated. However, the fact that strong evidence exists for the involvement of programed cell death in plant responses to salt stress (Katsuhara 1997; Wang et al. 2010) implies that it is highly likely that the cell death observed here for the maize genotypes could be a consequence of a programed cell death pathway. We are currently studying these maize genotypes to investigate if such cell death in response to salt stress is truly a consequence of a programed cell death process, by examining features that are hallmarks of programed cell death (DNA fragmentation presented as ladders on agarose gels, cytochrome c release and TUNEL assays). A preliminary indication that the cell death is likely to be via a programed cell death pathway, although necrotic death cannot be ruled out at this stage, is that caspase-like activity was augmented in the two maize genotypes in response to salt 
stress. It has been demonstrated that increased cysteine endopeptidase activity (in the form of caspase-like activity) in salt-stressed plants is indicative of programed cell death (Wang et al. 2010). It is thus appropriate to expect that the cell death observed for the two genotypes in response to salt is programed cell death. Similarly to the results of the cell death assay, caspase-like activity in the SK genotype is higher than that in the GR genotype in response to salt stress. The involvement of cysteine endopeptidase activity in response to salt stress was also demonstrated in Mesembryanthemum crystallinum leaves in which both mRNA and protein expressions were strongly induced by salt (Forsthoefel et al. 1998). Furthermore, expression of a cysteine endopeptidase in transgenic Arabidopsis plants altered salt tolerance (Chen et al. 2010).

The reduction of SOD activity in the roots of SK may be the result of the large (threefold) increase in the $\mathrm{O}_{2}{ }^{-}$in this genotype which may inhibit the SOD activity. In contrast to the roots, there was no large difference in the increase of $\mathrm{O}_{2}{ }^{-}$content in the shoots between the two genotypes; therefore the SOD activity was also greater after salt treatment in both genotypes. It is likely that regulation of SOD activity is one of the crucial determinants of the level of salt stress tolerance in the two maize genotypes. This is in agreement with a previous study in which it was demonstrated that the activity of SOD exhibited a greater increase following salt stress in salt-tolerant maize genotype than in sensitive ones (De Azevedo Neto et al. 2006).
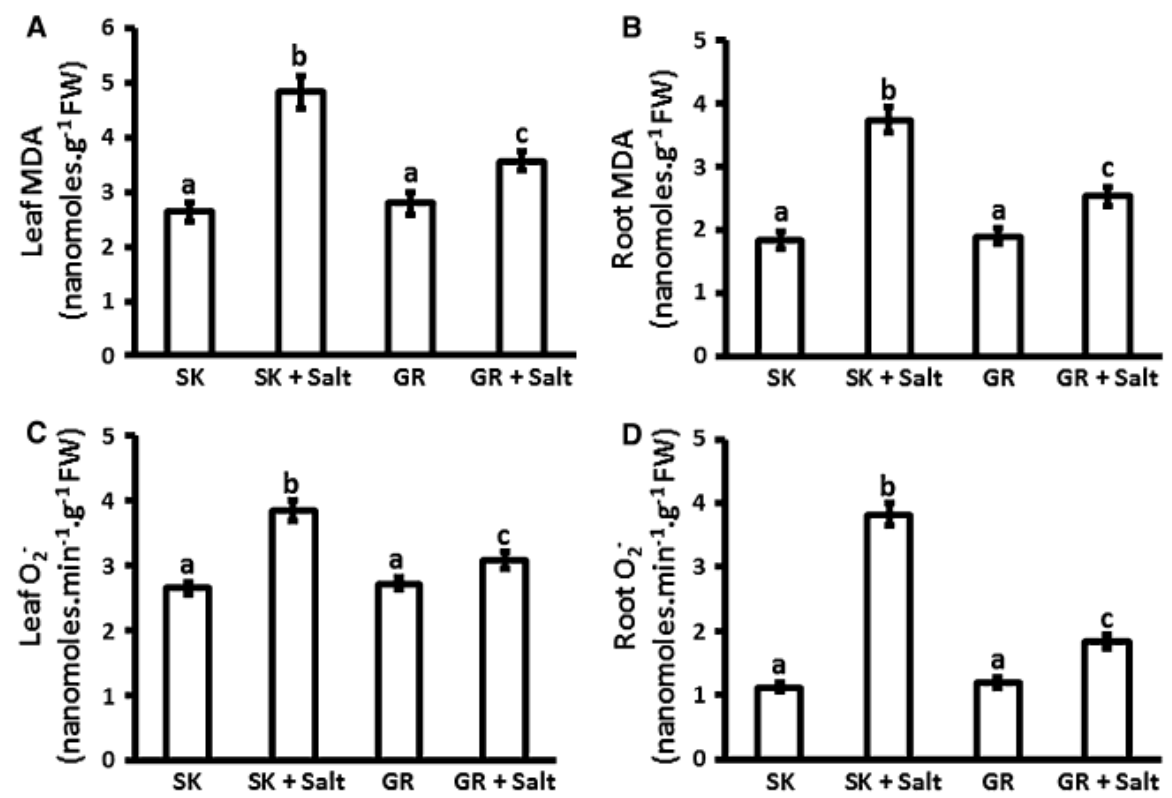

Fig. 4 Induction of lipid peroxidation and $\mathrm{O}_{2}{ }^{-}$accumulation by salt stress. Salt-induced changes in malondialdehyde (MDA) content in leaves (a) and roots (b) of the SK and GR genotype show a directly proportional relationship with leaf (c) and root (d) $\mathrm{O}_{2}{ }^{-}$content in response to salt treatment. MDA content and $\mathrm{O}_{2}{ }^{-}$accumulation in the

SK and GR maize genotypes were measured 21 days after treatment with the salt stress. Data represent measurements at the end of the entire salt treatment and are mean \pm standard enror of three different plants for each treatment, representative of three independent experiments

From comparison of pea genotypes with different salt tolerance, it turned out that SOD was induced both at transcriptional and enzymatic activity level in the tolerant genotype, but it was not affected in the sensitive one (Hernández et al. 2000). Enhanced salt 
tolerance was observed in transgenic tobacco overexpressing SOD (Badawi et al. 2004), which also corroborates the significant role of SOD in response to salt stress.

Accumulation of $\mathrm{O}_{2}{ }^{-}$can be countered by triggering SOD activity to bring $\mathrm{O}_{2}{ }^{-}$levels to basal levels, the result of which is the production of $\mathrm{H}_{2} \mathrm{O}_{2}$ (Beyer and Fridovich 1987; Foyer and Noctor 2005; Mittler 2002). The salt-induced changes in SOD enzymatic activity corresponded with altered $\mathrm{H}_{2} \mathrm{O}_{2}$ content in this study. This was also observed in rice (Lee et al. 2001). However, the fact that the roots of the SK genotype accumulated higher $\mathrm{H}_{2} \mathrm{O}_{2}$ levels in response to salt stress despite having inhibited SOD activity in response to salt suggests that other sources (e.g. glycolate oxidase, fatty acid oxidation, oxalate oxidase, amine oxidase and peroxidases such as $\mathrm{Mn}^{2+}$ and NADH oxidases) of $\mathrm{H}_{2} \mathrm{O}_{2}$ (Mittler 2002) also contribute to the accumulation of this ROS in response to salt stress in addition to SOD enzymatic activity. The importance of $\mathrm{H}_{2} \mathrm{O}_{2}$ in the stress response is indicated by its different concentrations in the two maize genotypes after salt stress. Similarly to maize, higher $\mathrm{H}_{2} \mathrm{O}_{2}$ was measured in the salt-sensitive rice genotype than in the tolerant one during salt stress (El-Shabrawi et al. 2010). In addition, the sensitive maize genotype showed elevated MDA content (and thus lipid peroxidation) that is more pronounced than the MDA content of the tolerant genotype in response to salt stress in the present study.

In detoxification of $\mathrm{H}_{2} \mathrm{O}_{2}, \mathrm{APX}$ is important and the efficiency with which the $\mathrm{H}_{2} \mathrm{O}_{2}$ is scavenged would be important in the determination of salt tolerance (higher APX activity may result in more efficient removal of $\mathrm{H}_{2} \mathrm{O}_{2}$ and thus lower $\mathrm{H}_{2} \mathrm{O}_{2}$ in the salt-tolerant genotype than in the salt-sensitive genotype). The involvement of APX in the response to salt stress was also demonstrated in rice, in which salt treatment resulted in greater APX activity, and certain isoforms were preferentially induced (Lee et al. 2001). In addition, the APX activity in a salt-tolerant tomato accession was inherently higher than in a saltsensitive cultivar, and this difference was also observed following salt stress (Shalata and Tal 2002). However, the contribution of catalase and glutathione peroxidase enzymatic activity to $\mathrm{H}_{2} \mathrm{O}_{2}$ removal may also be important.

We thus conclude that antioxidant capacity (i.e. the extent to which antioxidant enzymes detoxify/scavenge ROS) and caspase-like activity play a crucial role in regulating plant tolerance against salt stress.

Author contribution N. Ludidi designed and supervised the research work. M. Keyster grew the plants, determined tissue dry weights, cell viability, caspase-like activity, ascorbate peroxidase activity. A. Klein determined lipid peroxidation. M. Keyster and A. Klein performed the statistical analysis. M. Du Plessis determined superoxide dismutase activity; A. Jacobs determined the superoxide content and A. Kappo determined the $\mathrm{H}_{2} \mathrm{O}_{2}$ content. N. Ludidi, G. Kocsy and G. Galiba participated in the interpretation of the data 
and preparation of the manuscript. The final manuscript was read and approved by all the authors.

\section{Acknowledgments}

This work was supported by the University of the Western Cape, Stellenbosch University, the National Research Foundation (South Africa) and the National Office for Research and Technology (Hungary).

\section{Conflict of interest}

All authors declare that they have no conflict of interest. 


\section{References}

Able A, Guest D, Sutherland M (1998) Use of a new tetrazoliumbased assay to study the production of superoxide radicals by tobacco cell cultures challenged with avirulent zoospores of Phytophthora parasitica var nicotanae. Plant Physiol 117:491-499

Andronis EA, Roubelakis-Angelakis KA (2010) Short-term salinity stress in tobacco plants leads to the onset of animal-like PCD hallmarks in planta in contrast to long-term stress. Planta 231:437-448

Asada K (1984) Chloroplasts: formation of active oxygen and its scavenging. Method Enzymol 105:422-429

Badawi GH, Yamauchi Y, Shimada E, Sasaki R, Kawano N, Tanaka K (2004) Enhanced tolerance to salt stress and water deficit by overexpressing superoxide dismutase in tobacco (Nicotiana tabacum) chloroplasts. Plant Sci 166:919-928

Beyer WF, Fridovich I (1987) Assaying for superoxide dismutase activity: some large consequences of minor changes in conditions. Anal Biochem 6:559-566

Buege JA, Aust SD (1978) Microsomal lipid peroxidation. Method Enzymol 52:302-310 Chen HJ, Su CT, Lin CH, Huang GJ, Lin YH (2010) Expression of sweet potato cysteine protease $S P C P 2$ altered developmental characteristics and stress responses in transgenic Arabidopsis plants. J Plant Physiol 167:838-847

De Azevedo Neto AD, Prisco JT, Ené as-Filho J, de Abreu CEB, Gomes-Filho E (2006) Effect of salt stress on antioxidative enzymes and lipid peroxidation in leaves and roots of salt-tolerant and salt-sensitive maize genotypes. Environ Exp Bot 56:87-94

De Pinto MC, Locato V, De Gara L (2012) Redox regulation in plant programmed cell death. Plant Cell Environ 35:234-244 Ekmekç i Y, Tanyolaç D, Ayhan B (2008) Effects of cadmium on antioxidant enzyme and photosynthetic activities of two maize cultivars. J Plant Physiol 165:600-611

Ellouzi H, Hamed KB, Cela J, Munné-Bosch S, Abdelly C (2011) Early effects of salt stress on the physiological and oxidative status of Cakile maritima (halophyte) and Arabidopsis thaliana (glycophyte). Physiol Plant 142:128-143

El-Shabrawi H, Kumar B, Kaul T, Reddy MK, Singla-Pareek SL, Sopory SK (2010) Redox homeostasis, antioxidant defense, and methylglyoxal detoxification as markers for salt tolerance in Pokkali rice. Protoplasma 245:85-96

Forsthoefel NR, Cushman MAF, Ostrem JA, Cushman JC (1998) Induction of a cysteine protease cDNA from Mesembryanthemum crystallinum leaves by environmental stress and plant growth regulators. Plant Sci 136:195-206

Foyer $\mathrm{CH}$, Noctor G (2005) Redox homeostasis and antioxidant signaling: a metabolic interface between stress perception and physiological responses. Plant Cell 17:18661875

Gé mes K, Poó r P, Horvá th E, Kolbert Z, Szopkó D, Szepesi Á , Tari I (2011) Cross-talk between salicylic acid and $\mathrm{NaCl}$-generated reactive oxygen species and nitric oxide in tomato during acclimation to high salinity. Physiol Plantarum 142:179-192

Gossett DR, Millhollon EP, Lucas MC (1994) Antioxidant response to NaCl stress in salttolerant and salt-sensitive cultivars of cotton. Crop Sci 34:706-714 
Groten K, Dutilleul C, van Heerden PDR, Vanackera H, Bernard S, Finkemeier I, Dietz KJ, Foyer $\mathrm{CH}$ (2006) Redox regulation of peroxiredoxin and proteinases by ascorbate and thiols during pea root nodule senescence. FEBS Lett 580:1269-1276

He R, Drury GE, Rotari VI, Gordon A, Willer M, Farzaneh T, Woltering EJ, Gallois P (2008) Metacaspase-8 modulates programmed cell death induced by ultraviolet light and $\mathrm{H}_{2} \mathrm{O}_{2}$ in Arabidopsis. $\mathrm{J}$ Biol Chem 283:774-783

Herná ndez JA, Jimé nez A, Mullineaux P, Sevilia F (2000) Tolerance of pea (Pisum sativum L.) to long-term salt stress is associated with induction of antioxidant defences. Plant Cell Environ 23:853-862

Katsuhara M (1997) Apoptosis-like cell death in barley roots under salt stress. Plant Cell Physiol 38:1091-1093

Lee DH, Kim YS, Lee CB (2001) The inductive responses of the antioxidant enzymes by salt stress in the rice (Oryza sativa L.). J Plant Physiol 158:737-745

Li JY, Jiang AL, Zhang W (2007) Salt stress-induced programmed cell death in rice root tip cells. J Integr Plant Biol 49:481-486

Maia JM, Costa de Macedo CE, Voigt EL, Freitas JBS, Silveira JAG (2010) Antioxidant enzymatic protection in leaves of two contrasting cowpea cultivars under salinity. Biol Plant 54:159-163

Mallik S, Nayak M, Sahu BB, Panigrahi AK, Shaw BP (2011) Response of antioxidant enzymes to high $\mathrm{NaCl}$ concentration in different salt-tolerant plants. Biol Plant 55:191-195

Mandhania S, Madan S, Sawhney V (2006) Antioxidant defense mechanism under salt stress in wheat seedlings. Biol Plant 50:227-231

Miller G, Suzuki N, Ciftci-Yilmaz S, Mittler R (2010) Reactive oxygen species homeostasis and signalling during drought and salinity stresses. Plant Cell Environ 33:453-467

Mittler R (2002) Oxidative stress, antioxidants and stress tolerance. Trends Plant Sci $17: 405-410$

Mittler R, Vanderauwera S, Gollery M, Van Breusegem F (2004) Reactive oxygen gene network of plants. Trends Plant Sci 9:490-498

Naito Y, Fujie M, Usami S, Murooka Y, Yamada T (2000) The involvement of a cysteine proteinase in the nodule development in Chinese milk vetch infected with Mesorhizobium huakuii subsp. rengei. Plant Physiol 124:1087-1095

Noreen Z, Ashraf M, Akram NA (2010) Salt-induced regulation of some key antioxidant enzymes and physio-biochemical phenomena in five diverse cultivars of turnip (Brassica rapa L.). J Agron Crop Sci 196:273-285

Parida AK, Das AB (2005) Salt tolerance and salinity effects on plants: a review. Ecotox Environ Safe 60:324-349

Sairam RK, Srivastava GC, Agarwal S, Meena RC (2005) Differences in antioxidant activity in response to salinity stress tolerant and susceptible wheat genotypes. Biol Plant 49:85-89

Sanevas N, Sunohara Y, Matsumoto H (2007) Characterization of reactive oxygen speciesinvolved oxidative damage in Hapalosiphon species crude extract-treated wheat and onion roots. Weed Biol Manag 7:172-177 
Seckin B, Turkan I, Sekmen AH, Ozfidan C (2010) The role of antioxidant defense systems at differential salt tolerance of Hordeum marinum Huds. (sea barley grass) and Hordeum vulgare L. (cultivated barley). Environ Exp Bot 69:76-85

Shalata A, Tal M (2002) The effect of salt stress on lipid peroxidation and antioxidants in the leaf of the cultivated tomato and its wild salt-tolerant relative Lycopersicon pennellii. Physiol Plant 104:169-174

Solomon M, Belenghi B, Delledonne M, Menachem E, Levine A (1999) The involvement of cysteine proteases and protease inhibitor genes in the regulation of programmed cell death in plants. Plant Cell 11:431-443

Tseng MJ, Liu CW, Yiu JC (2007) Enhanced tolerance to sulfur dioxide and salt stress of transgenic Chinese cabbage plants expressing both superoxide dismutase and catalase in chloroplasts. Plant Physiol Biochem 45:822-833

Vaidyanathan H, Sivakumur P, Chakrabarty R, Thomas G (2003) Scavenging of reactive oxygen species in $\mathrm{NaCl}$-stressed rice (Oryza sativa L.)-differential responses in salt-tolerant and sensitive varieties. Plant Sci 165:1411-1418

Velikova V, Yordanov I, Edreva A (2000) Oxidative stress and some antioxidant systems in acid rain treated bean plants: protective role of exogenous polyamines. Plant Sci 151:59-66

Vincent JL, Brewin NJ (2000) Immunolocalization of cysteine protease in vacuoles, vesicles, and symbiosomes of pea nodule cells. Plant Physiol 123:521-530

Wang J, Li X, Liu Y, Zhao X (2010) Salt stress induces programmed cell death in Thellungiella halophila suspension-cultured cells. J Plant Physiol 167:1145-1151

Wu L, Zhang Z, Zhang H, Wang XC, Huang R (2008) Transcriptional modulation of ethylene response factor protein $\mathrm{JERF}_{3}$ in the oxidative stress response enhances tolerance of tobacco seedlings to salt, drought, and freezing. Plant Physiol 148:1953-1963 Zhang XX, Liu SK, Takano $\mathrm{T}$ (2008) Two cysteine proteinase inhibitors from Arabidopsis thaliana, AtCYSa and AtCYSb, increasing the salt, drought, oxidation and cold tolerance. Plant Mol Biol 68:131-143 